\title{
A CONSTITUTIONAL QUESTION IN CONNECTION WITH THE TORRENS SYSTEM OF LAND REGIS- TRATION.
}

In a paper read before the American Bar Association at its meeting in 1890 , Dwight $N$. Olmstead, Esq., declared the Torrens System of Land Registration, (an account of which has been recently given in this magazine by Charles $C$. Townsend, Esq.,) to be, on account of its provision for the examination of titles before admitting them to registry, impracticable in this country. Amongst other things Mr. Olmstead said: "No title, which has heretofore, for any considerable period of time, been dealt with according to the common law, can, with any certainty as to its condition, be entered on a register without a careful and reliable preliminary examination. All registry-of-title systems provide for such examinations. They may be made in countries where the transfers have been few and the ownerships large and capable examiners are employed, with comparative safety. But it is obvious that in such large cities as New York, where there are not far from 200,000 titles to land separately held, or even in smaller cities, prior examinations sufficiently reliable on which to warrant judicial decrees or state guarantees, would be impossible. In short, the Torrens system is not practicable, at least in this country:" Reports Am. Bar Ass'n., Vol. XIII., p. 27I et seg.

At the time Mr. Olmstead wrote, no one of the United States had adopted the Torrens system or any modification of it, but in 1895 the State of Illinois passed an act adopting in effect the Torrens system, and the feature criticized by Mr. Olmstead, having encountered and overcome the legislative objection of impracticability, has been assailed in court as unconstitutional, on account of the method provided for the examination and passing upon title before registry.

The Illinois Act of June I3, I895, (Laws of Ill., p. I07,) provides that the owner of an estate or interest in land, legal 
or equitable, and whoever has a power of appointment in fee simple, may apply to the Registrar of the county in which the land is situated, by a sworn application setting out, inter alia, a description of the land, the estate or interest of the applicant in the same; whether the land is occupied or unoccupied; if occupied, by whom; whether the land is subject to any lien or incumbrance, giving the name and address of the holder thereof and, if recorded, the book and page of the record ; and whether any other person has any estate or claims any interest in the land in law or equity in possession, remainder, reversion or expectancy, and if any, the address of said person and the nature of his estate or claim; that upon such application the Registrar shall cause examination to be made into the applicant's title and shall notify all persons, named in the application as having an interest in a lien or claim upon the land, of said application and post a copy of the notice upon the premises; the examiners shall then report upon the title; if they find defects therein, they are to give the applicant a reasonable time within which to remove them before finally passing upon his application; when the Registrar is satisfied of the validity of the applicant's title, he is to issue to him a certificate of title; if the Registrar be not satisfied, he is to dismiss the application without prejudice. After the issue of the certificate the registered owner shall hold subject only to such estates, mortgages, liens, charges and interests, as are noted in the certificate, and free from all others except any lease, written or verbal, not exceeding five years, under which there is an actual occupation, public highways, any easement, however created, upon, over or in respect of the land, any tax or assessment for which a sale of the land had not been had at the date of the certificate of title, the right of action or counter-claim allowed by the act, and the right of any person in possession of and rightfully entitled to the land or any part thereof or any interest adverse to the title of the registered owner, at the time when the land is first brought under the act and continuing in said possession until the issuance of the last certificate of title. The act further provides that, with the exceptions before mentioned, no person shall 
bring any action to recover land or assert any interest, or right in, or lien or demand upon the same or make entry thereon adversely to the title or interest certified in the first certificate bringing the land under the operation of the act, unless within five years after the first registration; and, further, that any person having any interest, right, title, lien or demand, whether vested, contingent or inchoate, in, to or upon registered land, existing at the time the land was first registered, but upon which no right of action had accrued at the date of registration, may, prior to the expiration of five years after the registration, file in the Registrar's office a sworn notice of his claim, and may bring an action to assert, recover or enforce the same at any time within one year after the right of action shall have accrued or within five years after the first registration and not afterwards.

Enough of the Illinois Act has been above set forth, it is thought, to enable the reader to understand the basis of the attack made upon the statute. The attack took, inter alia, the shape of a quo warranto to the Recorder of Deeds of Cook County for the purpose of ousting him from the office of Registrar of Titles (which by the act was vested in the Recorder,) on the ground that, as the statute required the Registrar, before allowing land to be registered and so brought within the operation of the act, to examine the title and be satisfied of its validity, judicial functions were conferred upon him, and that, as the Constitution provided that the judicial power should be vested in courts therein named or indicated, the act was unconstitutional as an attempt to vest judicial powers in an administrative officer. This contention met with success in the Supreme Court, which court held that what was required of the Registrar was the exercise of a judicial function. In arriving at this conclusion the court relied mainly on the following definition of judicial power given by Judge Cooley, viz.: "The power which adjudicates upon and protects the rights and interests of individual citizens, and to that end construes and applies the laws."

An examination of the matter will, it is thought, show that the conclusion of the court is supported neither by a consid- 
eration of what is meant by judicial power in the constitutional sense, nor by the definition given by Judge Cooley, when its terms are carefully attended to.

The endeavor of the framers of our federal and state governments was, undoubtedly, to separate, so far as practicable, the different departments of government and to carefully and positively define and distinguish from each other the executive, legislative and judicial departments. For all practical purposes the endeavor has been a success, and sufficient lines of demarcation have been established, but, nevertheless, such is the complexity of human affairs and business that it has been found impossible to keep the different powers, (if we define each power as an abstraction), from ever coming into contact. If, therefore, we regard as judicial, everything which involves a decision in the sense of making up the mind and causing such making up to have some effect upon the rights of others, we shall find that many acts are under our governmental system required to be done by officers who are not courts or parts of courts, the legality of which acts is unquestioned. Take, for example, the acts required of the Controller of the City :of Philadelphia, whose duty is defined in The Century Company v. Philadelphia, 38 Weekly Notes, 43 I, to be " to see that the various departments do not exceed their appropriations, nor apply them to purposes not within their proper scope." This certainly involves the duty on the part of the Controller of examining a bill presented to him for work directed by a department of the city administration, and of deciding, before he signs the warrant for payment for the same, whether the work is or is not within the scope of the department ordering it. So far as his action in signing or refusing to sign the warrant is concerned, it certainly has an effect, if not on the absolute right of the contractor with the department, at least upon the means to which he will have to resort to enforce his rights, if he have any.

Other examples of the same thing will readily occur to the reader-the action of the Register of Wills in admitting or refusing to admit to probate a will, the action of a Sheriff in distributing a fund in his hands, the action of the Auditors in 
different departments of the federal executive government, and, as a very marked example indeed, the action of the Patent Office through its examiners and commissioner in the issue of a patent. These and other instances may be given of the exercise of powers, which can be sustained as legal, only if the phrase, judicial power, has in its constitutional use and sense a technical and more confined meaning than one which would embrace every case where there is an exercise of judgment, in the popular sense, after a consideration of facts, and that exercise has some effect upon the right of another.

This position is abundantly supported by authority. In United States v. Ferreira, I 3 How. 40, it was held that an act of Congress empowering the district judge of Florida to examine and adjudge claims arising under the Florida treaty, and report his decision; when favorable, to the Secretary of the Treasury for his discretionary action thereon did not confer on the district court judicial power in the constitutional sense. The court, after referring to Hayburn's Case, 2 Dall. 4IO, and notes thereon, said: "The powers conferred by these acts of Congress upon the judge as well as upon the Secretary are, it is true, judicial in their nature; for judgment and discretion must be exercised by both of them. But it is nothing more than the power ordinarily given by law to Commissioners appointed to adjust claims to lands or money under a treaty, or special powers to inquire into or decide any other particular class of controversies in which the public or individuals may be concerned. A power of this description may constitutionally be conferred on a secretary as well as a commissioner, but it is not judicial in either case in the sense in which judicial power is granted by the Constitution of the United States." Again in Murray's Lessee v. Hoboken Land and Improvement Company, 18 How. 280, the distinction between the two senses in which the expression, judicial power, may be used is recognized. In delivering the opinion of the court, CuRTIS, J., says: "That the auditing of the accounts of a receiver of public money may be in an enlarged sense a judicial act must be admitted. So are the administrative duties, the performance of which involves an inquiry into the exist- 
ence of facts and the application to them of rules of law. In this sense, the act of the President in calling out the militia under the Act of 1795 , or of a commissioner who makes a certificate for the extradition of a criminal under a treaty is judicial. But it is not sufficient to bring such matters under the judicial power that they involve the exercise of judgment upon law and fact:" See, also, Taylor v. Place, 4 R. I. 324; Owners of Land v. People, I I3 Ill. 296, (and cases cited); Hawthorn v. People, rog id. 302 ; In re Clark, 65 Conn. 34; Stone v. Farmers' Loan \& Trust Co., I I6 U. S. 307 ; Reed v. Morton, I 19 Ill. I 18.

From this point of view, it is manifest that very little light can be shed upon the subject by those English cases which speak of the action of the Registrar being not only ministerial but judicial, for as the powers of government are not, in England, limited by any written constitution, and, as there is nothing to prevent Parliament conferring judicial powers, in any sense, upon a ministerial officer, the courts cannot distinguish between the two senses of judicial power which exist in this country, for in England the distinction does not exist.

What, then, is meant by judicial power in the constitutional sense, the judicial power which can constitutionally be exercised by courts only?

In answering this question, it is to be borne in mind that the judicial power is always spoken of and regarded in our constitutions, whether federal or state, as an attribute of government-the government is divided into the executive, legislative and judicial departments. Remembering, then, that what we are to define is a governmental function, the answer would seem to be, that judicial power in the constitutional sense is the power to make a decision in a controversy between parties, which shall, by its own force, be final and binding between said parties until reversed by the judgment and decision of a superior judicature. Final and binding, that is, without the necessity of any supplemental action or inaction on the part of any person or officer to bring about that effect. If, after the decision, it rests with any person or officer to put it into effect or not, then the action formulated in the so-called deci- 
sion is not a judicial action in the constitutional sense. This is illustrated by United States v. Ferreira, (supra.) The district judge heard testimony, examined and passed upon claims under the treaty, and certified his " decision," when favorable, to the Secretary of the Treasury, but, as it rested with the Secretary whether he would or would not act upon the "decision" of the judge, the action of the latter in making the decision was not in the constitutional sense judicial. To this characteristic finality of judgment or decision, in view of the fact that the judicial power we are considering is a function of a special department of government, should be added the authority on the part of the court or institution to carry into effect its decision or decree, either by means of its own officer or by an imperative direction to an executive officer. When we have the union of the right to decide, finally, between parties with the right to authoritatively direct the final decision, when made, to be carried into effect by force, we have judicial power in the full constitutional sense. If the power conferred upon an officer, or body of commissioners or governmental department, lack either of the above qualities, the power conferred is not judicial in the constitutional sense, although in its exercise it may require an examination of law and fact, and the application of one to the other.

Applying what has gone before to the duties and powers of the Registrar, under the Illinois statute, let us see whether he is vested with judicial powers in the constitutional sense. In the first place, does he make any decision which, by its own vigor, either vests or divests rights of parties? It is true that he is required, with the assistance of examiners learned in the law, to investigate a title presented to him for registry, to give notice to parties having claims to or liens upon the land of the applicant for a certificate, and to post a notice on the premises at least ten days before granting a certificate, and to refuse a certificate if he be not satisfied that the title is good and valid; but what is the effect of his decision either to grant or refuse a certificate? Does it vest or divest any right? It does of itself neither. If the Registrar refuse a certificate, then the act says " he shall dismiss the application without 
prejudice and return the papers to the applicant," deciding nothing. If the Registrar grant a certificate, does it bar any adverse rights or give forthwith to the recipient any right or title which he had not before the grant of the certificate? Not at all ; it merely starts, as to him and in his favor, except as. against estates, liens and interests mentioned in the certificate and certain statutory exceptions, a period of limitation, within which any claim, any title, can be urged by suit against his certificated title or possession, but on the expiration of which his title becomes, except as above indicated, indefeasible. The fixity of his title is due to the running of the period of limitation. Before the termination of that time the certificate is not even prima facie evidence of title; possession with it is no. stronger than possession without it; at the end of the period the certificate becomes conclusire. Have we here anything which is contrary to the ordinary course of the running of the statute of limitation, except that it requires a matter of record to start it, and is this the only case in which a privilege is attached to land or obtained by the owner thereof by means of a record? An example of so obtaining a privilege at once occurs in the statute providing that where the ownership of land in the city of Philadelphia is registered in the Registry Bureau, the land shall not be sold for taxes except after suit against the registered owner, a privilege not possessed by non-registered land. Does the fact that care is to be taken before permitting registry convert the act of registry from an administrative to a judicial action? Another example prompts a negative answer. Patents are not issued until after the claims of the inventor are examined by skilled officials, questions of interference or priority may be passed upon by the commissioner, but that does not render the action of the Patent Office judicial; the patent may be attacked, the invention shown not to be that of the patentee, an interference be shown in the court, just as freely as if the patent had not been granted, or as if the practice were to grant patents to all who applied for them, leaving their recipients to fight out question of right amongst themselves in the courts, without any prior examination in the Patent Office. 
Assuredly, then, it is not in accordance with the analogies of the law in similar cases to hold that because an act which is to start the running of a period of limitation looking to the quieting of title is carefully guarded that, therefore, it is to have less effect than the same act would have if performed without such guards. It cannot be questioned that the Legislature has power to pass a statute of limitations of any reasonable character, or that it can make any act the startingpoint of the running of the period of limitation. There would be nothing unreasonable in the enactment that the filing of a title, with due notice by one in possession, or even without notice, should be a bar to all actions for land not bought within a given period, and that thereafter the land should be brought within the act and be transferred according to its provisions. This, in effect, was the simple plan suggested by Mr. W. Strickland Cookson, in $1857, i$.e., to place possessory titles on the register upon an affidavit of the supposed owners as to their condition and to allow them to mature by lapse of time, careful official supervision being given to intermediate transfer. This, according to Mr. Olmstead, was substantially followed by Mr. Charles F. Brickdale in his Registration of Titles to Land (Lond., 1886,) and appeared in the statement of the Land Laws by the Council of the Incorporated Law Society of the United Kingdom (Lond., I886,) and is apparently also approved by Mr. Olmstead himself. This being the case, how the requirement of care and examination, before permitting a land owner to proceed to bring his land within the protection of a new system of registration and transfer can make that which, without such care, was perfectly legal, illegal and unconstitutional, seems hard to comprehend, when we bear in mind the distinction between judicial powers in the general and in the constitutional sense.

It remains to say a few words upon the support given to the theory that the Registrar's action is judicial, by the definition quoted by Judge Cooley, to quote it again: "The power which adjudicates upon and protects the rights and interests of individual citizens, and to that end construes and applies the laws." Now this definition to stand (and we believe it will 
stand without giving much aid to the theory for which it is cited), must be taken as a whole and read so that the protection afforded is to be regarded as a consequence of the adjudication; for it is manifest that other departments of government do, in a very practical sense, often protect the rights and interests of individuals, without exercising of judicial power. Now adjudicate has a technical and special meaning. In the Latin, adjudico is to adjudge or award a thing to one; as judge to declare it to be his. Andrew's Lexicon, giving as authority, Cicero, Livy, Suetorius. Abjudico is to give sentence as judge against one; to declare that he has forfeited something. Worcester gives the following definitions: Adjudicate, to sentence, to adjudge, to pass judgment; adjudge, (I) to give or award by the decision of a judge or umpire; (2) to settle, to determine, to decree by judicial sentence; (3) to condemn, to sentence; (4) to judge, to deem. Webster gives the following : Adjudicate, to adjudge, to try and determine as a court, to try and determine judicially; adjudge, to decide or determine in the case of a controverted question, to decree by judicial opinion. The Century Dictionary: Adjudicate, to adjudge, pronounce judgment upon, award judicially, to sit in judgment, give a judicial decision; adjudge, (I) to award judicially, assign; (2) to decide by a judicial opinion or sentence, adjudicate upon, determine, settle; (3) to pass sentence upon, sentence or condemn; (4) to deem, judge, consider; (rare), to decree, decide, pass sentence.

It will be observed that primarily all the definitions look to the action of a court or judge, in the popular sense, to the decision of a cause between parties, a decision which determines a question of right in favor of one as against the other party; a decision which has finality; a decision, the carrying out of which may be compelled by the power which has rendered it. That Judge Cooley used the word " adjudicate" in this sense, is not only probable from the general use of it, but is apparent from his coupling it with the idea of protection- " adjudicates and protects." The judicial power first declares what is the right of the individual before it, and then by its process puts him in possession of his right, or protects him in its enjoy- 
ment. Taking, then, the word "adjudicate," in the sense in which Judge Cooley must have used it, there is nothing in the quotation which at all supports the theory it is called upon to support, for the Registrar determines and enforces no right; he has no compulsory process to bring persons before him and to compel them to show their rights or their claims; he issues no execution, or process after he has given his certificate of title, moved thereunto by the petition of the land owner, he bars by his certificate no right, he simply declares that the applicant has convinced him, the Registrar, that he has a certain title, and that title is upon record, if within the period fixed by the statute no action is brought for the land, the title becomes unassailable by the operation of the statute of limitation, and, thereafter, the land is to be sold and transferred by a new, convenient and economical method, instead of by the cumbersome and expensive one at present employed.

Considered upon general principles, or even taking the definition of judicial power, attributed to Judge Cooley, as conclusive, it does not seem to us that the functions given to the Registrar of Titles, are, in the constitutional sense, judicial, and it is to be hoped that the Supreme Court of Illinois, before whom a motion for a reargument of the question is pending, may not adhere to its first expressed opinion and so impede the progress of what many consider one of the great legal reforms of the age.

Henry Budd.

Philadelphia, February 5, I897. 